\title{
XIV ENCONTRO NACIONAL DE GEÓGRAFOS - ENG/2006 A GEOGRAFIA E A AMAZÔNIA NO CONTEXTO LATINO- AMERICANO: DIÁLOGOS, PRÁTICAS E PERCURSOS
}

\author{
Camila Salles de Faria*, Fabiana Valdoski Ribeiro* e Felipe Schaeffer Bianchetti***
}

Após 30 anos sem um Encontro na região Norte neste ano de 2006 tivemos a oportunidade de debater e conhecer um fragmento da realidade da Amazônia, através do XIV Encontro Nacional de Geógrafos sediado na Universidade Federal do Acre, nos dias 16 à 21 de julho, em Rio Branco, no qual nos debruçamos sobre os desafios que a globalização impõe a esta porção do território brasileiro.

A Conferência de Abertura se destacou por apresentar um debate entre dois geógrafos de referência aos estudos a respeito da Amazônia com matrizes de interpretação distintas, Bertha Becker e Carlos Walter Porto Gonçalves. A primeira abordou os desafios dos impactos decorrentes da globalização, centrando sua análise na produção de territórios coorporativos, na medida em que se mercantilizam os elementos da natureza. Já Carlos Walter destacou o protagonismo dos movimentos sociais e suas resistências, que "geo-grafaram" o território da Amazônia, e hoje reafirmando a necessidade de uma intervenção desses sujeitos nos processos em curso na região.

Ao longo das mesas redondas, comunicações coordenadas e espaços de diálogos e práticas os temas versaram sobre: a geopolítica do desenvolvimento latino-americano; um balanço do pensamento geográfico brasileiro; a atual realidade dos povos da floresta, assim como dos movimentos sociais e suas lutas por acesso a terra, a luz dos novos projetos governamentais e intervenções privadas; a relação entre o urbano e o rural pensada por meio da divisão territorial brasileira; a polêmica questão da água e seus usos; os grandes projetos mineroenergéticos e seus impactos ambientais e sociais; as situações das populações tradicionais (ribeirinha, indígena principalmente); o papel do professor de geografia no século XXI e o turismo.

Dentre as atividades do Encontro tivemos os trabalhos orientados com ou sem saída ao campo, enfocando principalmente as políticas públicas regionais, como os relacionados as Reservas Extrativistas e Reforma Agrária, ao turismo, a gestão de recursos hídricos e a experiência de Plano Diretor.

O Encontro homenageou dois grandes geógrafos brasileiros. O Professor Aziz Nacib Ab'Sader pela exposição de Carlos Augusto de Figueiredo Monteiro, intitulada "uma trajetória pela geografia e pela Amazônia", na qual destacou a vida acadêmica do pesquisador desde a época de estudante até hoje em dia. A outra apresentada por Ariovaldo Umbelino de Oliveira foi uma homenagem póstuma para o Professor Orlando Valverde, na qual ressaltou as obras e sua importância para o pensamento geográfico, sendo finalizada com um documentário produzido pela AGB contendo depoimentos sobre suas contribuições.

Na Plenária Final foi eleita a nova chapa da AGB Nacional, porém não se definiu a próxima sede o que será deliberado nas RGCs. Significando a possibilidade de qualquer seção local se candidatar.

*Aluna do Programa de Pós-graduação em Georgrafia Humana pelo Departamento de Goegrafia - USP. E-mail: camsalles@yahoo.com.br

** Aluna do Programa de Pós-graduação em Geografia Humana pelo Departamento de Geografia - USP. E-mail; fabivaldoski@yahoo.com.br *** Aluno do Programa de Pós-graduação em Geografia Humana pelo Departamento de Geografia - USP. E-mail: 